\title{
Effect of Work Motivation with Working Discipline in Nursing Performance in Special Unit X Hospital in Yogyakarta
}

\author{
Sri tungga dewi*, Tri Pitara Mahanggoro**, Mariska Urmila*** \\ *Correspondent Author: Dewi.kendari01@gmail.com \\ *Master of Hospital Management, Universitas Muhammadiyah Yogyakarta, Indonesia \\ **Faculty of Medicine and Health Science, Universitas Muhammadiyah Yogyakrta, Indonesia \\ *** PKU Bantul Hospital, Bantul City, Daerah Istimewa Yogyakarta, Indonesia
}

\begin{tabular}{l}
\hline I N D E X I N G \\
\hline Keywords: \\
Motivation \\
Disipline \\
Performance
\end{tabular}

\begin{abstract}
A B S T R A C T
The research was conducted at $\mathrm{X}$ hospital which aims to determine the effect of work motivation, work discipline on the performance of nurses in the inpatient room. The data obtained has been analyzed using descriptive analysis and quantitative analysis. Quantitative analysis used multiple regression analysis to determine the effect of independent variables on the dependent variable, but before the test is carry out the validity and reliability has been tasted, sampling was using total sampling technique where the population is equal to the number of samples as many as 47 nurses. The results of the study revealed that work motivation factors had a significant effect on the performance of nurses in X hospital, while the discipline factors did not have a significant effect on the performance of nurses of $\mathrm{X}$ hospital while the influence of work motivation and work discipline on performance shows a positive number which means there is an influence on performance. The results of the study revealed that motivation factors had a significant effect on performance as $(0.041)$ which means that $\mathrm{h} 0$ was rejected and $\mathrm{h} 1$ was accepted. While the results of work discipline on performance did not have a significant effect, value of the discipline as $(0.750)$ where the value is bigger than the standard value of error $(0.05)$ which means $\mathrm{h} 0$ was accepted and $\mathrm{h} 1$ was rejected. From the research, it was found that the human resources at $\mathrm{X}$ hospital were still lacking in terms of motivation and in terms of work discipline the quality of human resources had improved.
\end{abstract}

Kata kunci:

Motivasi;

Disiplin;

kinerja
Penelitian ini dilakukan di rumah sakit X yang bertujuan untuk mengetahui pengaruh motivasi kerja, disiplin kerja terhadap kinerja perawat di ruang khusus rawat inap. Data yang diperoleh dianalisis menggunakan analisis deskriptif dan analisis kuantitatif. Analisis kuantitatif menggunakan analisis regresi berganda untuk mengetahui pengaruh variabel independen terhadap variabel dependen, tetapi sebelum pengujian dilakukan validitas dan reliabilitas telah diuji, pengambilan sampel menggunakan teknik total sampling dimana populasi sama dengan jumlah sampel sebagai sebanyak 47 perawat. Hasil penelitian menunjukkan bahwa faktor motivasi kerja berpengaruh signifikan terhadap kinerja perawat di rumah sakit X, faktor disiplin juga berpengaruh signifikan terhadap kinerja perawat rumah sakit $X$. Hasil penelitian menunjukkan bahwa faktor motivasi memiliki pengaruh yang signifikan terhadap kinerja sebagai $(0,049)$ yang berarti bahwa ho ditolak dan hl diterima. Sedangkan hasil disiplin kerja terhadap kinerja memiliki pengaruh yang signifikan, nilai disiplin $(0,047)$ dimana nilainya lebih kecil dari nilai standar error $(0,05)$ yang berarti h0 ditolak dan $h 1$ diterima. Dari hasil penelitian, ditemukan bahwa sumber daya manusia di rumah sakit $X$ masih kurang dalam hal motivasi dan dalam hal disiplin kerja terhadap kinerja. Disarankan kepada manajemen Rumah Sakit Kabupaten Bantul PKU Muhammadiyah untuk: memberikan penghargaan bagi perawat yang telah melakukan dalam asuhan keperawatan yang baik dan benar sesuai standar yang ditetapkan dan memberikan hukuman bagi perawat yang belum optimal dalam kinerjanya. Memberikan pelatihan untuk perawat yang belum pernah mengikuti pelatihan asuhan keperawatan, terutama mereka yang terlibat langsung dengan pelaksanaan asuhan keperawatan di rumah sakit.

(C) 2018 JMMR. All rights reserved

Article history: Received 2018-Sep-15; Revised 2018-Dec-16; Accepted 2018-Dec-17

\section{INTRODUCTION}

The hospital is an institution that is formed by the needs of an increasingly sophisticated society because people are aware of the importance of health. The hospital is strived to provide maximum service to the society. These efforts will become more difficult if faced with changes and challenges in this very rapid international era, this challenge is felt for all types of industries to competing each other, one of them 
is the industry in the field of health services. The existence of high-quality hospital human resources and professional is very needed 1 .

Human resources in this case is employees, they are the main source of strength. The company's goal can be achieved if the employee's performance is good. Employee performance is work performance or the results can be seen in terms of quantity and quality standards that have been determined by an organization. Good performance is optimal performance, accordance with organizational standards and to supports achieve of goals an organization. A good organization is who can improve the ability of human resources as an aspect to improve employee performance. Employee performance can increase if the employee's needs can be fulfilled, there will be a special satisfaction for employees. An employee in fill up his needs must bde have high motivation and discipline towards his work. ${ }^{2}$

Motivation and work discipline are important factors that can be affect employee performance. The company instills motivation and work discipline in employees for the sake of persevering employees in working. The role of a company leader can motivate employees to encourage them to work actively. $\frac{3}{-}$

Motivation of work that exists in the employees accompanied by good work discipline are two aspects that are expected by the company. The company can encourage employees to be highly motivated to achieve company goals. Motivation and work discipline also applies to nurses who work in $\mathrm{X}$ hospital in the implementation of activities. Giving rewards to employees who can reach the target can be as a work motivation for all levels of human resources in $\mathrm{X}$ hospital. Not only rewards that the hospital used to increase motivation, they are salary increases, promotions and work allowances as a consideration to improve hospital performance. Formulation of the Problem (1) there is any eefect of work motivation and work discipline simultaneously on the performance of nurses in the special care unit room of X Hospital in Yogyakarta? (2) Does work motivation have a partial effect on the performance of nurses in the special care unit room of $\mathrm{X}$ Hospital in Yogyakarta? (3) Does work discipline have a partial effect on the performance of nurses in the special care unit room of X Hospital in Yogyakarta? The Objectives of the Study (a) General Objective: This study generally aims to describe the effect of work motivation and discipline work for nurses in the special care unit of $\mathrm{X}$ Hospital in Yogyakarta. (b) Special Objective (1) Determine the effect of the work motivation of nurses in the special care unit room X Hospital in Yogyakarta (2) Determine the effect of the work discipline of nurses in the special care unit room $\mathrm{X}$ Hospital in Yogyakarta (3) Determine the effect of work motivation and work discipline of nurses in the special care unit room X hospital in Yogyakarta.

Significance of the study (1) for hospital management: For evaluation materials and as a basic for recommendations to those who make health service policies, especially hospital management to improve work motivation and work discipline on the performance of nurses. (2) For Readers: The results of this study can be useful for the reader as an additional source of information related to work motivation with work discipline. (3) For Authors: This study is expected to be useful in the application of knowledge that the author has gained during the lecture and add insight, knowledge and experience of the author about the effect of work motivation and discipline on nurses in the special care unit room $\mathrm{X}$ hospital in Yogyakarta.

The Concept of Motivation According to motivation is a mental state and a human mental attitude that provides energy, moves or encourages activities and leads or transmit behavior to achieve needs that giving satisfy or reduce imbalances ${ }^{4}$. Motivation is formed from the attitude of employees in dealing with work situations in carry out their work, also explains motivation is the condition and energy that moves the employee who is directed or aims to achieving organizational goals ${ }^{5}$. Moreover, state that motivation is a willingness to implement organizational goals in this case is the ability to attempt to meet individual needs. The source of motivation, the motivation theory that always used in the explanation of motivation sources is basically divided into two sources of motivations, according to the motivation sources consists of intrinsic motivation and extrinsic motivation (a) Intrinsic motivation: Intrinsic motivation because of a motive that appear from a person without an external encouragement to do something, in this intrinsic motivation a person can do something consciously and appear from his own desires (b) Extrinsic motivation: Extrinsic motivation appear because of the external individual, which is not contained in the action itself or beyond his knowledge $\stackrel{6}{\text {. }}$

Motivation theories, Abraham Maslow's motivation theory describes a theory of human motivation or a theory of human motivation as an encouragement for a variety of needs, Maslow's opinion of the desired needs of each individual means that if the first need is fulfilled, then the second need will be main. Furthermore, if the second level needs are fulfilled, then the next level will appear again and 
until the fifth level needs ${ }^{2}$. The motivation theory developed states that every human being consists of five levels or hierarchy of needs, namely: (1) Physiological Needs (2) Safety Needs (3) Social Needs (4) Award Needs (5) Self-Actualization ${ }^{-}$. Mc Clelland's achievement needs theory, need theory states that this motivation theory focuses on three needs namely achievement, power and affiliation, this theory has been widely adopted in various organizations. The following needs theory according to $\mathrm{Mc}$ Clelland as follows: (1) Needs for achievement (2) need for power (3) Need for Affiliation ${ }^{6}$. Herzberg's theory, proposed the theory of two factors: motivational factors and maintenance factors, the implementation of a job is strongly influenced by two factors as needs, namely: (1) Motivator Factor, (2) Hygiene Factor? .

The Objectives of Motivation, according to the objectives of giving motivation is: (a) Increase / encourage passion and enthusiasm in work (b) Increase job satisfaction and morale (c) Increase productivity (d) Maintain stability and loyalty (e) Increase discipline and reduce absenteeism (f) streamline procurement (g) Creating a good working relationship and atmosphere (h) Increase participation and creativity (i) Improve welfare (j) Increase responsibility with tasks. The Concept of work discipline, According to work discipline is a person's awareness and willingness to comply with various organizational regulations and prevailing social norms. Work discipline is used by leaders to communicate with employees so that they are willing to change their behavior and follow the rules of the game. Discipline must be upheld without the support of good work discipline, it is difficult to realize organizational goals because discipline is the key to the success of an organization in achieving a goal. $\stackrel{10}{-}$

Types of Work Discipline, namely: (a) Preventive discipline: Preventive discipline is an effort to encourage someone to follow and conform the work rules sthat et by the organization. Preventive discipline aims to direct and encourage someone to work with discipline (b) Corrective discipline: Corrective discipline is an effort to encourage someone to unite a rule and can direct it to comply with the rules in accordance with the guidelines that apply in each organization. Corrective discipline also has punishmant if someone commits a disciplinary offense that aims to get a deterrent effect and can improve themselves and comply with the rules ${ }^{-}$.

Factors that influence work discipline, according to the good badness of someone's discipline in work does not appear just like that, but there are several factors. The following are several factors that influence employee work discipline, namely: (a) Presence (b) Adherence to work regulations (c) Adherence to work standards (d) Alertness high level (e) Ethical work. $\stackrel{11}{=}$

The Concept of Performance, According to suggests that performance is the result of work achieved by a person or group of people in an organization, which is appropriate with their respective responsibilities and authority, in order to achieve the organization's objectives legally, not violating the law and appropriate with ethics and morals. Performance is the level of success of a person or institution in carrying out its work. Factors Affecting Performance: (a) Effectiveness and efficiency (b) Authority (c) Discipline (d) Initiative. $\frac{12}{}$

Special Nursing Room, Guidelines for PKU Muhammadiyah hospital services based on their structure explain the definition of special care space is a ward in a hospital equipped with special staff and equipment to treat patients who are threatened by a single organ or multiple failure. Dysfunction due to a disease, disaster or complications that still have life expectancy. Special care services must be carried out by staff who are formally trained and able to provide optimal services and free from other burdensome tasks. Working staff must participate in the system to ensure the continuity of 24-hour special services. The parts of special care are: (1) Emergency Installation (IGD) (2) Intensive Care Unit (ICU) (3) Surgery Room (OK) (4) High Care Unit (HCU).

Theoretical framework

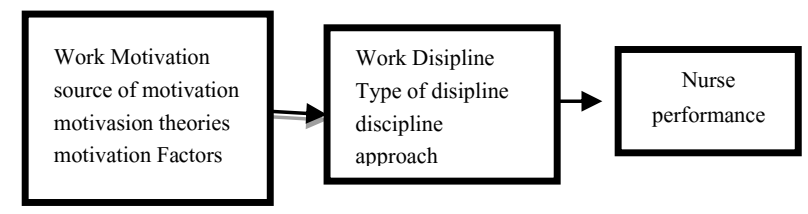

Picture 1. Research theory framework $\frac{13}{-3}$ 


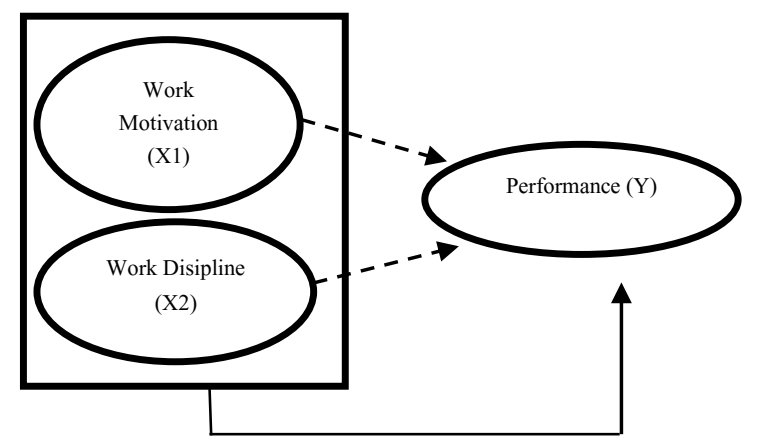

Picture 2.Conceptual Framework

Source: processed by researchers based on existing literature

partial influence

Simultaneous influence

Hypothesis, H1: Motivation and work discipline have a positive effect on the performance of nurses in X hospital, $\mathrm{H} 2$ : Motivation has a positive effect on the performance of

\section{RESEARCH METHOD}

Type and Design of the Study, The type of this study is descriptive quantitative and the design is cross sectional design. Location and Time of Research this study carried out in a special care room at X hospital in April 2018. Population and Sample of the Study (1) Population the population of this study were nurses in a special care in the $\mathrm{X}$ hospital which numbered 47 people. (2) Sample to detrmine the sample of this study the researcher used total sampling technique. Total sampling is a sampling technique where the number of samples is the same as the population ${ }^{14}$. The reason for taking total sampling because the population less than 100 then the entire population is sample. The sample of this study is 47 people. (a) Inclusion Criteria (1) Nurses who have worked in a special care room installation for at least one year (2) Nurses who are permanent employees in X (3) Nurses who are not ongoing a study assignments. (b) Exclusion Criteria (1) Nurse who serves as head of space.

Research Variables (1) Independent variable (Independent variable) (2) Dependent variable (Dependent variable). Techniques of Data Collection (a) Type of the data this study requires two types of data, namely: (1) Primary Data The primary data needed in this study are data from questionnaire motivation and work discipline on nurses, some of the data obtained using check lists on respondents was obtained directly from the research object (2) Secondary data, secondary data needed in this study is nurses in $\mathrm{X}$ hospital, H3: Work discipline has a positive effect on the performance of nurses in $\mathrm{X}$ hospital.

indirectly data from the object of research, namely data or files of $\mathrm{X}$ hospital. This data or files is form the nurse attendance from May 2017 to July 2017. Method of Data analysis (1) Validity test, Validity test is a procedure in ensuring the validity or failure of a questionnaire that will be used to measure research variables. Before being used for research, it is necessary to test the validity of the research instrument because it relates to the accuracy and suitability of the function of the measuring instrument to be used. Research instrument is considered valid if it can measure or present what will be measured. Test the validity of the measuring instrument, first find the correlation between the parts of the measuring instrument as a whole by correlating each item of the measuring instrument with the total score which is the sum of each item score (2) Reliability Test, Reliability is an index that shows how far a research instrument is reliable or reliable. Reliability shows that the measurement results of these instruments remain consistent if measurements are made twice or more by using the same measuring instruments on the same symptoms ${ }^{15}$. The instrument of this research was computerized reliability testing using the Cronbach Alpha formula. Alpha values between 0.8 to 1.0 is categorized as good reliability, alpha values between 0.6 to 0.79 are categorized as acceptable reliability, and alpha values less than 0.60 are categorized as poor reliability.

Technique of Data analysis (1) univariate Analysis, Univariate data analysis of this study was used to describe 
or explain the characteristics of each variable and the results of study to produce a percentage and distribution of each variable (2) Bivariate Analysis, According to, two variables that are thought to be correlated or related need to be carried out bivariate analysis. The Spearman rank test was used as a statistical test of this study, the Spearman rank test was done by computerization (3) Multivariate analysis, the statistical test used to test the research hypothesis is multiple statistical analysis and partial correlation analysis techniques. Multiple regression analysis techniques are used to examine the effect of independent variables with variables dependent together. While partial correlation analysis techniques are used to test the pure relationship between independent variables and dependent variables by controlling other independent variables. $\frac{15}{-}$ Research ethics is an important problem considering that research will relate to one's privacy so good ethics is needed. The cover letter was accompanied by a research proposal to ask for research permission to the head of the $\mathrm{X}$ hospital. The introductory letter contains requests for permission, research subjects, research time and things to be achieved from the research.

After getting permission, the respondent interviewed and emphasized the existing ethical principles, but first asked the respondent's willingness and explained the purpose of the research, this step was also used in distributing questionnaires to the respondents, guaranteeing the confidentiality of respondents before filling out the questionnaire would be maintained. The ethical rules in research include:

(1) The approval sheet is given to the respondent of the study before the research is conducted, if the respondent is willing to sign the consent sheet, but if not then he or she is not forced and continues to respect the rights of the research sample. (2) Confidentiality, guaranteed confidentiality of research results, both information and other issues. All information that has been collected is guaranteed confidentiality. (3) Without a name, to maintain confidentiality the researcher will not include the respondent's name.

The special care room is a hospital room consisting of an emergency room, ICU, OK and $\mathrm{HCU}$ and equipped with special staff and equipment to treat and treat patients who are threatened by one organ or multiple failure / dysfunction as well as dealing with serious patients due to illness, trauma, complications, disaster or who still have life expectancy. Special care services must be carried out by special staff or doctors trained and formally experienced and able to provide optimal service and free from other burdensome tasks. Working staff must participate in the system to ensure continuity of 24-hour special services.

\section{Table 1. Characteristics of Respondents}

\begin{tabular}{|c|c|c|}
\hline \multicolumn{3}{|c|}{ Characteristics of Respondents } \\
\hline No & Category & total \\
\hline \multirow[t]{3}{*}{1} & Age & 31-35 (15 Respondents) \\
\hline & & 36-40 (25 Respondents) \\
\hline & & 41-45 (7 Respondents) \\
\hline \multirow[t]{2}{*}{2} & Gender & 38 women \\
\hline & & 9 man \\
\hline \multirow[t]{2}{*}{3} & Education Levels & D3 (39 Respondents) \\
\hline & & S1 (8 Respondents) \\
\hline \multirow[t]{4}{*}{4} & Long Working & $1-5$ (5 respondents) \\
\hline & & 6-10 ( 24 Respondents) \\
\hline & & 11-15 ( 15 Respondents) \\
\hline & & 16-20 (3 respondents) \\
\hline
\end{tabular}

The age of respondents between 31-35 years old was 15 respondents, age 36-40 years as many as 25 respondents, age 41-7 years the number of respondents was 7 respondents. The total respondents overall were 47 respondents. The number of respondents in $\mathrm{X}$ hospital nurses was more dominant, namely 38 respondents while the number of male respondents was 9 respondents. nurses who worked in X hospital with D3 education were 39 respondents while respondents with $\mathrm{S} 1$ education were 8 respondents, the number of working time of nurses in $\mathrm{X}$ Hospital, 1-5 years as many as 5 respondents, 6-10 years as many as 24 respondents, $11-15$ years as many as 15 respondents and in 16-20 years there were 3 respondents, total respondents are 47 . 
Table 2. Coefficients

\begin{tabular}{|c|c|c|c|c|c|c|c|}
\hline & \multirow[b]{2}{*}{ Model } & \multicolumn{2}{|c|}{ Unstandardized Coefficients } & \multicolumn{4}{|c|}{ Standardized Coefficients } \\
\hline & & B & Std. Error & Beta & & $\mathbf{t}$ & Sig. \\
\hline \multirow[t]{3}{*}{1} & (Constant) & 27.534 & 4.115 & & & 6.691 & .000 \\
\hline & motivasi & .057 & .028 & & .280 & 2.029 & .049 \\
\hline & disiplin & .168 & .101 & & .261 & 2.018 & .047 \\
\hline
\end{tabular}

\section{Dependent Variable: kinerja}

Work motivation variable (X1) with a value of $t$ count 2.029 and the value is greater than t table (2.014) with a significant level of 0.049 (smaller than 0.05). Ho refused $\mathrm{Ha}$ accepted. Based on this, it can be concluded that the work motivation variable is partially positive and significant towards the nurse's performance $(\mathrm{Y})$, this means giving a positive and significant contribution to the performance of nurses at $\mathrm{X}$ hospital. Work discipline variables (X2) The value of $t$ count is 2.018 and is greater than $t$ table (2.014) with a significant level of 0.47 (smaller than 0.05). Ho is rejected and Ha is accepted, considering that it can be concluded that the work discipline variables are partially positive and significant towards the performance of nurses (Y) this contributes positively and significantly to the performance of nurses at PKU Muhammdiyah Bantul hospital.

Table. 2 Test Results Simultaneous Regression of Variable Work Motivation (X1) and Work Discipline (X2) on Nurse Performance (Y) at PKU Muhammadiyah Hospital Bantul.

\begin{tabular}{cccccc}
\hline Model & Sum of $\boldsymbol{R}$ Square & $\boldsymbol{d f}$ & Mean Square & $\boldsymbol{F}$ & Sig \\
\hline 1 regression & 12.241 & 2 & 6.120 & 4,111 & $.023^{\mathrm{a}}$ \\
Residual & 65.504 & 44 & 1.489 & \\
Total & 77.745 & 46 & & \\
\hline
\end{tabular}

In the table above, it can be seen that $\mathrm{F}$ test obtained $\mathrm{F}$ count value of 4.111 with probability $(\mathrm{p}=0.023)$. This shows that $\mathrm{F}$ count $(4,11)>\mathrm{F}$ table $(3,21)$. That is, Ho is rejected, which means that work motivation and work discipline together have a positive and significant effect on the dependent variable of nurse performance. The $t$ test is done to test whether each independent variable, namely the variable work motivation and work discipline, has a positive and significant influence on the dependent variable of nurse performance partially Test result: (a). Hypothesis testing used in the $\mathrm{t}$ test is as follows: $\mathrm{H} 0: \mathrm{b} 1=\mathrm{b} 2=0$, meaning that together, there can be no positive and significant effect of the independent variables, namely work motivation and work discipline on the dependent variable of nurse performance. $\mathrm{H} 0$ : $\mathrm{b} 1 \neq \mathrm{b} 2 \neq 0$, meaning that together there is a positive and significant effect of the independent variables namely work motivation and work discipline on the dependent variable of nurse performance.
Based on this study, there are other studies that are similar to this variable, The results with linear regression test shows that there is an influence of achievement, acknowledgment, responsibility, development, salary, working condition, interpersonal relationships, and supervision to the performance of nurses. From eight motivational variables, the variable that gives biggest effect to the performance of nurses is Job. Based on these results, it is suggested that Stella Maris Hospital Makassar should pay attention to several aspects of the performance of nurses. It needs to be improved further so that operations can run smoothly. $\underline{16}$

The result of the research shows that the variables related to the performance of inpatient nurses are work discipline with low relation strength, while work environment is unrelated. Hospitals are suggested to standardize their operational procedures of technical aspects of nurse work. Hospitals are also suggested to provide hand-washers and antiseptic soaps that are easily accessible so that inpatient nurses can wash their hands first 
before starting work. Meanwhile, nurses are demanded to obey the rules and utilize their work time well. $\frac{17}{-}$ The result indicates that there was relationship between discipline and working burder with nurse performance and working burden relates to nurse performance in intensive care unit of Regional Public Hospital Undata Palu. It is suggested to the hospital officers to be more paying attention to nurse's performance and the duty given to them should be based on their capacity or abality so it can increase their performance. $\frac{18}{}$

The results showed that motivation and discipline that are in good enough category, job satisfaction and performance of nurses is in the category of high or good enough. partial effect of motivation on job satisfaction of nurses working in sumedang district general hospital by $11.4 \%$ and the discipline of work on job satisfaction of nurses in sumedang district general hospital by $47.1 \%$. as for the influence of motivation and discipline of work simultaneously on job satisfaction of nurses at the general hospital of sumedang amounted to $61.7 \%$. in addition, test Results found the influence of job satisfaction on the performance of nurses by $53.7 \%$. 19 The results of this study indicated that motivation dan work discipline simultaneously affects of the performance employees at Reksa Waluya Hospital Mojokerto. Regression obtained showed that each of the independent variables (motivation and work discipline) used in the study has significant effect and showed positive signs. This indicates that higher motivation and more consciousness to perform discipline at work will influence employee's performance. $\frac{20}{}$

\section{CONCLUSION}

The conclucion are: work motivation and work discipline have no effect simultaneously on the performance of nurses in $\mathrm{X}$ hospital. Work motivation has a significant effect on the performance of nurses in $\mathrm{X}$ hospital. Work discipline does not affect the performance of nurses in X hospital.

Suggestion, As input for policy makers and policy decisions at $\mathrm{X}$ hospital, the authors gave the following suggestions: (1) Increased motivation from within yourself as well as the direction of the leader to his subordinates to be able to be more maximal in completing the work and serving the community so that the goal of the PKU Muhammdiyah Bantul hospital is achieved. (2) Improving the performance of nurses in $\mathrm{X}$ hospital in the form of motivation and work discipline needs to be considered, improved and developed. (3) Increased work motivation and work discipline should be held a special meeting to discuss related work motivation between superiors and subordinates as well as periodic evaluations so that it is known the obstacles faced in the problem of nurse performance.

\section{REFERENCE}

1. Badi'ah, Mendri, R., Sutrisno, Lena, R. 2008. Relationship of Nurse Motivation with Nurse Performance in the Inpatient Room of Bantul Panembahan Senopati Hospital. Ahmad Dahlan University.

2. Guritno, B. And Waridin., 2005. The Effect of Employee Perception on Leadership Behavior, Job Satisfaction and Motivation to Performance. JRBI, Vol. 1, pp. 63-74.

3. Marpaung, Iga Mawarni, Djamhur Hamid, Mohammad Iqbal. 2014. Journal of Business Administration. Malang: Faculty of Administrative Sciences Universitas Brawijaya.

4. Sinungan, Muchdarsyah. 2005. Productivity: What and How. Jakarta: PT. Bumi Aksara.

5. Mangkunegara. 2007. Human Resource Management. Bandung: PT. Teen Rosdakarya.

6. Robbins, Stephen P. 2006. Organizations Behavior. Jakarta: PT Indeks, Kelompok Gramedia.

7. Priansa, D, J. 2014. Human Resource Planning and Development. Bandung: Alfabeta.

8. Widianti, Emilia. 2012. The Effect of Work Motivation, Work Discipline and Organizational Culture on the Performance of Health Employees at Panti Secanti Gisting Hospital. IBM ASMI Jakarta: Thesis.

9. Hasibuan, Malayu S. P. 2005. Human Resource Management. Jakarta: Bumi Aksara.

10. Sinambela, L. 2017. Human Resource Management. Jakarta: PT. Bumi Aksara.

11. Rivai, Veithzal Ahmad Fawzi Mohd. 2005. Performance assessment. Jakarta: Rajawali Press

12. Prawirosentono.S, 1999. Human Resource Management, Employee Performance Policy Yogyakarta: BPFE.

13. Gibson, James L, James H., Donnelly, Jr., John M., Ivancevich. 1987: Behavior, Structure, Process, Fifth Edition, Volume 1, Interpretation of Djarkasih. Jakarta: Erlangga.

14. Sugiyono, 2009, Metode Penelitian Kuantitatif, Kualitatif dan R\&D, Bandung : Alfabeta 
15. Notoatmodjo, S. 2010. Health Research Methodology. Jakarta: Rineka Cipta

16. Makta, La ode. 2013. The effect of work motivation on the performance of nurse at inpatient hospital unit in stella maris hospital makassar: Tesis

17. Sutrisnoputr, Alessandra Lourdes. 2018. Relationship of work discipline and work environment with nurse performance in the general hospital room tugurejo region semarang: Tesis

18. Arifuddin, Adhar. 2015. Relationship of discipline and work loads with nurse performance in the infrastructure of the regional general hospital palm undata: Journal

19. Sudan, Yonius. 2016. The effect of motivation and discipline of work on work satisfaction and its implications in nurse performance in the sumedang regional general hospital : Journal

20. Susan, W.M. 2012, Influencer of motivation on performance in the public security sector with a focus to the police force in nairobi kenya, Internasional Journal od Bussness and Social Science. 